\title{
КОНТЕНТНА КОЛАБОРАЦІЯ ЯК ПЕРСПЕКТИВА ЗАБЕЗПЕЧЕННЯ ЯКОСТІ ОСВITИ
}

\author{
Національна медична академія післядипломної освіти імені П. А. Шупика
}

\begin{abstract}
Підкреслена проблема різкого зростання обсягів інформації в усіх галузях знань. Показано, що особливу незахищеність перед «лавиною» слабоструктурованих знань отримують учасники освітнього процесу. Виділена проблема низького співробітництва фахівців предметної області при створенні єдиної тематичної бази. Зроблений висновок про необхідність розвитку контентної міжінституційної колаборації фахівців з медичних предметних областей на основі методологій формалізації і структурування контенту, а також використання стандартів трансформації та передачі знань.
\end{abstract}

Ключові слова: освіта, передача знань, неструктурована інформація, взаємодія фрахівців.

\section{КОНТЕНТНАЯ КОЛЛАБОРАЦИЯ КАК ПЕРСПЕКТИВА ОБЕСПЕЧЕНИЯ КАЧЕСТВА ОБРАЗОВАНИЯ}

\author{
В. В. Краснов

\begin{abstract}
Национальная медицинская академия последипломного образования имени П. А. Шупика
\end{abstract}
Подчеркнута проблема резкого роста объемов информации во всех отраслях знаний. Показано, что особую незащищенность перед «лавиной» слабоструктурированных знаний получают участники образовательного процесса. Выделена проблема недостаточного сотрудничества специалистов предметной области при создании единой контентной базы.

Предложены основные принципы контентной коллаборации в высшем медицинском образовании на Украине: 1. Обеспечение коммуникации - через прямое взаимодействие и дистанционную связь, что позволяет добиться эффекта присутствия. 2. Решение противоречий - с помощью «круглого стола» с конечной целью: достижение консенсуса. 3. Первичное структурирование знаний - используя карты памяти. 4. Вторичное структурирование и представления контента - на основе инженерии знаний с разработкой онтологий декларативных и процедурных знаний. 5. Эволюционирование - на основе обеспечения обратной связи от потребителей контента, а также постоянного трансфера новых слабоструктурированных данных с научных институтов в направлении экспертов предметных областей в системах образования. 6. Преемственность - на основе использования международных стандартов.

Сделан вывод о необходимости развития контентной межинституциональной коллаборации специалистов по медицинским предметным областям на основе методологий формализации и структурирования контента, а также использования стандартов трансформации и передачи знаний.

Ключевые слова: образование, передача знаний, неструктурированная информация, взаимодействие специалистов.

\section{CONTENT COLLABORATION AS PERSPECTIVE TO ENSURE QUALITY OF EDUCATION}

\section{National Medical Academy of Postgraduate Education by P. L. Shupyk}

\begin{abstract}
There is a problem of exponential information growth in all fields of knowledge. It is shown that the special vulnerability to the "avalanche" of semistructured knowledge are getting participants in the educational process. The problem of low collaboration between data domain experts in creating a single content database is highlighted.

A main principle of content collaboration in Ukraine higher medical education is proposed: 1. Ensuring communication either through direct communication and remote communication, to achieve the effect of presence. 2. The decision conflicts - with the help of the "round table" with the ultimate goal: achieving a consensus. 3 . Primary structuring knowledge - using a memory card. 4. Re-structuring and presenting content - based on knowledge engineering to the development of ontologies declarative and procedural knowledge. 5. Evolve - by providing feedback from the consumers of content, as
\end{abstract}

(C) В. В. Краснов 
well as the permanent transfer of new semi-structured data from scientific institutions in the direction of domain experts in the education systems. 6. Continuity - based on the use of international standards.

The conclusion is based on the need of development of inter-institutional content collaboration between specialists for medical subject areas. Collaboration based on methodologies of formalization and structuring of content and the use of standards for the transmission and transformation of knowledge.

Key words: ed ucation, knowledge transfer, unstructured information, interaction of specialists.

Вступ. В останнє десятиліття поняття інформаційного вибуху стало звичною фразою в різних професійних спільнотах. Згідно з багатьма дослідженнями цифрового простору, світ в 2010 році подолав бар'єр обсягу світової інформації в 1 зеттабайт і вступив в еру мегаданих (Bigdata) й проблема продовжує поширюватись, так як світовий обсяг інформації подвоюється кожні 18 місяців і швидкість його росту збільшується. Більшість дослідників відзначають іiі екстраневизначений характер, порівнянний з хаосом, слабку структурованість і низький рівень захищеності даних. Багато вчених почали говорити про ризики інформаційної сингулярності, що може призвести до непередбачуваних наслідків для людства [1]. 3'явилися терміни «інформаційне перевантаження», «інформаційний шум», «інформаційний колапс» [2] тощо. Вважається, що при подальшому нарощуванні обсягу інформації, інформаційне середовище до 2020 року перетвориться на інформаційне звалище [3]. При цьому важливо відзначити, що фактично людьми використовується менше $3 \% 323 \%$ потенційно корисних даних [4]. Більше того - велика частина цифрового контенту не унікальна - майже 75 \% всього обсягу цифрового світу є копіями [5]. За іншими оцінками, більше 95 \% цифрового середовища складається 3 неструктурованих даних, 3 якими доводиться працювати дослідникам [6].

Виникає наступне питання - яким чином інформаційне перевантаження може вплинути на систему освіти? Досить тривалий час посередником між неструктурованою інформацією і учнем був викладач. На його плечі покладалося завдання представляти навчальний матеріал у вигляді, зручному для сприйняття, а також супроводжувати цей матеріал до моменту його «абсорбції» учнем. 3 появою Інтернету і вільного доступу до необмеженого контенту, «захисний прошарок» між учнем та інформацією у вигляді викладача втратив свою актуальність. 3 цього моменту той, хто навчається, отримав можливість самостійно приймати рішення - 3 якою інформацією йому взаємодіяти. Як наслідок, роль викладача стала розмиватися і набувати дещо інших обрисів, що визначаються інформаційним століттям. Одночасно відбувалися зміни і у вимогах до тих, хто навчається.
Наприклад, радою Європи визначено п'ять ключових компетенцій, якими повинні бути оснащені молоді європейці [7]. Дві з них пов'язані із зростанням інформатизації суспільства - здатністю організовувати усну та письмову комунікацію і умінням використовувати інформаційні технології. Остання компетенція більш детально відображена в документі під назвою "Керівництво з інформаційної грамотності для освіти впродовж усього життя" [8], в якому під грамотністю розуміють здатність ідентифікувати потребу в інформації, навички з ефективного їі знаходження, оцінки і використання. Крім того, за оцінками експертів, ті, хто навчається, займають і будуть займати все більш важливу роль у розробці контенту, беручи участь у процесах само- та взаємонавчання [9].

У свою чергу, не менш значимі вимоги покладаються і на викладачів, делегуючи їм нові ролі методистів, консультантів, порадників і наставників тих, хто навчається, а також ставлячи їм функції з оцінки та інтерпретації знань у процесах їх передачі, створення та отримання [9]. Все це може бути ефективно реалізовано тільки при забезпеченні безперервного професійного розвитку викладачів.

Метою дослідження $є$ обгрунтування важливості співробітництва розробників змісту навчання на міжінституціональному рівні в медичній освіті.

Результати й обговорення. Останнє десятиліття ознаменувалося активним рухом, коли окремі викладачі й цілі університети стали не тільки відкривати вільний доступ до освітнього контенту, але й підтримувати вільне навчання бажаючих.

Одним $з$ перших проектів відкритого доступу, який подав приклад багатьом іншим університетам, став проект Массачусетського технологічного інституту (MIT OpenCourseWare), що стартував у 2002 році 3 метою вільної публікації матеріалів всієї своєї освітньої програми. Спочатку передбачалося, що ресурсом будуть користуватися студенти та випускники МIT або викладачі інших вузів. Але результат дослідження в 2009 році показав: більше половини аудиторії складають люди, які займаються самоосвітою. Крім того, OCW привів до підвищення якості викладання в самому навчальному закладі, оскільки збільшив відпо- 
відальність професорів за підготовку матеріалів, які публікувалися для широкої аудиторії [10].

ЮНЕСКО підтримав ініціативу створення відкритих освітніх ресурсів. У цьому проекті сьогодні беруть участь більш ніж 150 найбільших університетів з 21 країни світу, кожен з яких надав у відкритий доступ власні навчальні матеріали в рамках консорціумy Open Coure Ware (http://www.ocwconsortium.org/) [1]

Основна ідея, до якої апелюють ініціатори відкритого навчання, полягає у твердженні, що навчена людина змінює свій погляд на життя. $Є$ цілий ряд обставин, за якими людина не може собі дозволити не тільки аудиторне навчання, але і платне віртуальне (сім'ї з низьким рівнем доходів, невпевненість у необхідності нових платних знань, побоювання придбати низькоякісні знання тощо). У свою чергу, при отриманні освіти когнітивні картини світу набувають ще більшої структурованості, що приводить до того, що така людина приймає більш обгрунтовані рішення і у своєму житті, і в житті соціального оточення. Низка міжнаціональних досліджень показала, що більш високий рівень освіти корелює з підвищенням цінності демократії, важливості особистої свободи, свободи вибору і терпимості до іншого способу життя в уявленнях людей [12]. Для країн третього світу безкоштовне навчання може бути практично єдиним шансом підвищити добробут громадян своєї держави. Крім того, згідно з останніми дослідженнями, людина освічена може генерувати нові знання, що реалізується в нових відкриттях, якими надалі користується весь світ.

Проте відкриття освітнього контенту несе в собі цілий ряд загроз. Перш за все - це збільшення і так величезного обсягу інформації, яка з'являється у відкритому доступі. У свою чергу, кожен, хто навчається, сам стає «генератором» нової інформації. $€$ і ще одна проблема, пов'язана з концепцією слабкої структурованості знань, що можна представити на такому прикладі. У всьому світі існує понад 20 тисяч вищих навчальних закладів [13]. Наприклад, у кожному ВНЗ читається обов'язкова дисципліна зі світової історії, соціології та інших природничих наук. Якщо концепція відкритого навчання буде підтримана всіма ВНЗами, то при різних стандартах навчання та індивідуальної інтерпретації контенту викладачами, в світ може вийти понад 20 тисяч курсів зі світової історії з високим ступенем відмінності один від одного і наборами суперечностей. До яких соціальних зрушень все це може призвести у віддаленому наслідку не може спрогнозувати ніхто, але зіткнен- ня різних ментальних моделей соціальних процесів історія знає достатньо.

Тому перед людством постає суперечливе завдання - як забезпечити одночасно і універсальність і варіабельність освітнього контенту, щоб уникнути шаблонної уніфікації та забезпечити різноманітність соціальних і професійних діалогів, тому що абсолютної істини людство ще не досягло. У свою чергу, забезпечення універсальності також є проблематичним, якщо згадати цифри, які вже наводилися вище близько 95 \% існуючої в доступі інформації слабо структуровано, що при індивідуальній обробці їх експертами призводить до досить високої особистісної інтерпретації.

На наш погляд, для вирішення зазначених суперечностей необхідно створити систему координації співробітництва експертів у розробці уніфікованої базової частини навчального контенту предметної області, чітко відділяючи їі від варіативної частини, вільної для особистісної інтерпретації.

Серед вчених ідея колаборації (пор.-в.-лат. collaborare, від con - 3, i laborare - трудитися, син.: cпівпрацювати) не нова. Одним 3 яскравих прикладів є експеримент KamLAND, який об'єднав зусилля 12 лабораторій США і Японії, задіявши 93 вчених зі світовою популярністю [14]. Також широко відомі розробки вченими інтерпретаційних наукових словників тощо.

На жаль, серед фахівців зі створення освітнього контенту, особливо в медицині, подібні приклади співпраці не представлені широко. 3 одного боку, це можна виправдати специфічністю і закритістю медичної галузі, яка безпосередньо пов'язана 3 таємницею особистості. 3 іншого боку, самі викладачі ще не повністю готові до того, щоб віддавати свою роботу на загальний огляд і використання. Тут діють ще стереотипи дотримання авторського права, питання фінансової компенсації витрачених зусиль, низька узгодженість професійних медичних шкіл тощо. У результаті в системі медичної освіти має місце, як мінімум, неефективне використання кадрових ресурсів (наприклад, близько 20 вищих медичних навчальних закладів можуть розробляти відмінний контент 3 одного й того ж предмета), а як максимум держава набуває неоднаковий зміст компетенцій фахівців, які навчалися в різних ВНЗ.

Крім того, при підготовці освітнього контенту рідко використовуються світові стандарти. Це призводить до того, що сховища навчальної інформації - погано систематизовані, не структуровані і сильно перевантажені зайвою інформацією набори знань. У свою 
чергу, в т.ч. і через відсутність стандартів, не дотримується історична і внутрішньопрофесійна наступність контенту. Ця тенденція набула настільки поширеного характеру, що для того, щоб дати характеристику проблемі невикористання попередніх напрацювань, ЮНЕСКО почав використовувати терміни: «темний інформаційний вік», «цифровий Альцгеймер», «цифрова амнезія» тощо [15].

Сучасна прикладна наука в процесі свого розвитку розробила інструментарій, за допомогою якого можна забезпечити ефективну колаборацію. Проте в основі ініціації такого процесу лежить усвідомлена згода професійного співтовариства до реальної взаємодії і розуміння необхідності створення уніфікованої базової частини навчального контенту. Ми вважаємо, що контентна колаборація у вищій медичній освіті в Україні повинна будуватися на основі наступних принципів :

1. Забезпечення комунікації - через пряму взаємодію та дистанційний зв'язок, який дозволяє домогтися ефекту присутності.

2. Вирішення суперечностей - за допомогою технології «круглого столу» 3 кінцевою метою досягнення консенсусу.

3. Первинне структурування знань - використовуючи карти пам'яті.

4. Вторинне структурування і представлення контенту - на основі інженерії знань $з$ розробкою онтологій декларативних і процедурних знань.

5. Еволюціонування - на основі забезпечення зворотного зв'язку від споживачів контенту, а також постійного трансферу нових слабоструктурованих да-

\section{Лтература}

1. Вороненко Ю. В. Ризик виникнення освітньої сингулярності: тенденції та можливі наслідки / Ю. В. Вороненко, О. П. Мінцер // Медична інформатика та інженерія. - 2013. - № 1. - С. 4-11.

2. Еляков А. Д. Информационная перегрузка людей / А. Д. Еляков // Социологические исследования. - 2005. № 5. - C. 114-121.

3. Gantz J. Extracting Value from Chaos, IDC 1142 / J. Gantz, D. Reinsel. - 2011. - Режим доступу: http://www.emc.com/ collateral/analyst-reports/idcextracting-value-from-chaosar.pdf.

4. Gantz J. The Diverse and Exploding Digital Universe: An Updated Forecast of Worldwide Information Growth Through 2011 / John F. Gantz, Christopher Chute, Alex Manfrediz, Stephen Minton, David Reinsel, Wolfgang Schlichting, Anna Toncheva // IDC White Paper, 2008. - Режим доступу: http:/ /www.ifap.ru/library/book268.pdf. 2012-02-28.

5. Gantz J. The Digital Universe Decade - Are You Ready? / J. Gantz, D. Reinsel. - Мау 2010. - Режим доступу: http:// них з наукових інституцій в напрямку експертів предметних областей в системах освіти.

6. Наступність - на основі використання міжнародних стандартів при розробці: форматів зберігання і пошуку навчальної інформації; принципів побудови систем управління навчанням; форматів обміну даними; інформації про учасників навчального процесу; елементів освітнього контенту; форматів і принципів розробки навчальних матеріалів. Наприклад: Content Management Interoperability Services (CMIS), SCORM (Sharable Content Object Reference Model - модель обміну навчальними матеріалами); специфікації консорціуму Всесвітньої Освіти IMS / GLC (Instructional Management System Global Learning Consortium) тощо.

Крім того, необхідна політична воля самих медичних ВНЗ щодо більш активного створення єдиного освітнього простору на міжінституційному і міждержавному рівнях на основі використання тематичної колаборації, нових інформаційних технологій і стандартів знань.

Висновки. 1. Забезпечення контентної міжінституційної колаборації фахівців з медичних предметних областей дасть можливість ефективно розробляти базові, уніфіковані компоненти дисциплін, відповідних сучасному міжнародному рівню.

2. Контрольований трансфер наукових даних є основою випереджальної підготовки фахівців.

3. Успішність створення навчальних предметних областей залежить від методологій формалізації і структурування контенту, а також від використання стандартів трансформації та передачі знань.

www.emc.com/digital_universe.

6. Журавлева Е. Ю. Эпистемический статус цифровых данных в современных научных исследованиях / Е. Ю. Журавлева // Вопросы философии. - 2012. - Режим доступу: http:/ $/ \mathrm{vph}$ i l. r u / i n d e x.ph p ? o p t i o n $=$ com_content\&task=view\&id=473\&Itemid=52\#_edn 18 .

7. Hutmacher Walo. Key competencies for Europe // Report of the Symposium Berne, Switzerland 27-30 March, 1996. - Peжим доступу: http://www. eric.ed.gov/ERICWebPortal/ contentdelivery/servlet/ERICServlet?accno=ED407717.

8. Хесус Лау. Руководство по информационной грамотности для образования на протяжении всей жизни / Лау Хесус. - 2006. - Режим доступу: www.ifap.ru.

9. Кронбергская декларация о будущем процессов приобретения и передачи знаний, UNESCO, 2007. - Режим доступу: http://www.ifap.ru/ofdocs/rest/kronberg.pdf.

10. Steve Carson. The unwalled garden: growth of the OpenCourseWare Consortium, 2001-2008 / Carson Steve // Open Learning. - 2009. - Vol. 24. - №> 1. - P. 23 - 29. 
11. Парижская Декларация 2012 г. по ООР. - Режим доступу: http://www.unesco.org/new/fileadmin/MULTIMEDIA/ HQ/CI/CI/pdf/Events/Russian_Paris_OER_Declaration.pdf. 12. Инглхарт Р. Развитие и демократия: что мы знаем о модернизации / Р. Инглхарт, К. Вельцель // Социология. - 2011. - №> 1. - C. 44-54.

13. Webometrics Ranking of World Universities. - Режим доступу: http://www.webometrics.info/index.html. 14. Araki T. Experimental investigation of geologically produced antineutrinos with KamLAND / T. Araki et al. // Nature. - 2005. - №> 436. - c. 499-503.

15. Fedorov Alexander. On Media Education / A. Fedorov. Moscow: ICOS UNESCO "Information for All", 2008. - 156 p. 